\title{
Names in Dialect: Introduction
}

\section{ALLAN METCALF}

Coavs oals to Newcastle. Roses by different names. Does any reader of Names have to be told that onomastics and dialectology are kissing cousins, often bedfellows, sometimes two sides of the same coin?

If so, let that improbably obtuse reader look at any ordinary issue of Names; there will plentifully appear examples of the link between the study of names and the study of language variation. In 1983 alone, and not counting book reviews, Names had articles on geographic variation of nationalistic place names in the United States; upstate vs. downstate in New York; the American terms creek, run and hollow; Celtic names in the American North and South; surnames in the Southern United States; geographical spread of English place-name surnames; changing place names in New Mexico, and the development of ethnic epithets from personal names.

All of these topics would have been equally at home in American Speech, journal of the American Dialect Society, whose readers recently have been treated to studies of "Criminal Monickers" and "The Hairbender Beauty Salon de Paris of Ethel." Substantial works on names have likewise appeared in the monograph series Publication of the American Dialect Society, from Frederic G. Cassidy's exemplary The Place Names of Dane County, Wiscon$\sin$ (No. 7, 1947) to Virginia O. Foscue's The Place Names of Sumter County, Alabama (No. 65, 1978).

Names and dialect. Which field is the handmaiden, which the maid; which is the branch and which the clinging vine; which the host and which the parasite, may sometimes seem at issue, but it is more often a matter of whether the left hand should serve the right, or which hat a scholar cares to put on.

And indeed, the practitioner is often the same. As readers of this journal well know, American scholarly interest in names took much of its impetus from members of the American Dialect Society, some of whom helped with the birth of the American Name Society. Five different scholars have been independently chosen as presidents of both societies - namely, Kemp Malone, Allen Walker Read, Frederic G. Cassidy, Audrey R. Duckert, and 
John Algeo. Shortly after the Name Society was founded, E.C. Ehrensperger started his ever-growing series of annual reports on place-name studies at the behest of the Dialect Society (the first is in PADS 23 [April 1955]: 58). The reports grew to serve both societies amicably for some time until the Name Society took over the responsibility a decade ago.

But to properly illustrate the whole connection between dialect and name studies would require more than a whole issue of Names. This essay is supposed to be a prologue, not a retrospect.

What, then, does this issue of Names have to offer? It offers, not a definitive summary, but a sampling: six ways of studying names in dialect, or dialect in names, onomastic dialectology or dialectal onomastics. The approaches are as varied as the authors, who have in common simply an active interest in dialect and names.

A prominent name heads the list of authors for the first article: Raven I. McDavid, Jr. He and his co-workers on the Linguistic Atlas of the Middle and South Atlantic States demonstrate anew the interconnection of Linguistic Atlas work with place-name studies. For the onomastic detective, the appendix of this article offers more than a hundred previously unpublished place names, some still in need of further identification.

Moving westward to the Mississippi valley, the next article by Timothy C. Frazer, finds a historical and cultural explanation for the unexpected prevalence of Northern place names in the Midlands speech areas of Illinois. The very fact that names can pattern otherwise than the common vocabulary does makes them valuable in accounting for complexities in dialect distribution. They provide an indication of who among the early settlers had local prestige, social and linguistic.

Further to the west, and much to the south, in San Antonio, Texas, Scott Baird uses street names and the city name to test hypotheses about local pronunciation. Such names are readily elicited and sensitive to local standards. In this case, the names of San Antonio confirm the existence of three, or even four, local varieties of English.

Personal names, too, claim the attention of dialectologists. The article by McDavid et al., though concerned with toponymy, shows the importance of personal names in determining both origin and spelling of place names. The last three articles deal with personal names in their own right.

Werner Enninger, in the fourth article, not only describes and classifies by-names used by the Amish in the United States, but also considers their function as socio-psychological markers. Careful analysis of the different kinds of by-names enables precise discussion of conditions governing their use.

The fifth article deals with onomastics at the highest level of government. 
Heretofore strangely absent from scholarly scrutiny, though it has given the public pause and created at least one linguistic joke, is the last name of the fortieth President of the United States. I have taken the opportunity of this special issue to offer evidence of semantic differentiation between the two pronunciations of Reagan, as well as the President's establishment of a new norm for the pronunciation of Regan in the teeth of the prevailing pattern.

In a final note, George $J$. Metcalf offers examples of contrasts between spelling and pronunciation of personal names, contrasts cooked up by America's melting pot. The possibilities seem endless, but he wonders if the combination of foreign spelling and Anglicized pronunciation might be dying out.

The American Name Society has made a name for itself publishing scholarship concerned with variation in names. This special issue on a familiar theme happily acknowledges a relationship that needs no reminding.

McMurray College 